\title{
ENERGY-INDEPENDENT BINDING OF IRON COMPLEXED TO SMALL ORGANIC CHELANTS BY NEISSERIA MENINGITIDIS
}

\author{
MAR PINTOR, CARLOS M. FERREIRÓS,* AND MARÍA T. CRIADO \\ Departamento de Microbiología y Parasitología, Facultad de Farmacia, \\ Universidad de Santiago de Compostela, Spain
}

(Received July 6, 1993; Accepted November 26, 1993)

\begin{abstract}
$\mathrm{Fe}^{3+}$-dicitrate binding and iron uptake from citrate have been characterized in three carrier and three case isolates of Neisseria meningitidis. Culture in $\mathrm{Fe}^{3+}$-dicitrate rich medium did not induce subsequent $\mathrm{Fe}^{3+}$-dicitrate binding as it does for Escherichia coli and other bacteria. Growth in iron-restricted conditions slightly stimulated the $\mathrm{Fe}^{3+}$-dicitrate binding system in all the strains studied. Total binding of citrate as $\mathrm{Fe}^{3+}$-dicitrate was 2.5 times that of citrate in the absence of iron. Affinity for $\mathrm{Fe}^{3+}$-dicitrate ranged from $6.3 \times 10^{4}$ to $2.6 \times 10^{5} \mathrm{l} / \mathrm{mol}$, and the number of receptors per cell ranged from 8,500 to 64,800 . The binding system was highly specific for $\mathrm{Fe}^{3+}$-dicitrate (it did not bind other iron complexes with isocitrate, lactate, pyruvate or EDDA). Fe uptake efficiency was significatively higher in the case strains but, due to the higher number of receptors per cell in the carrier strains, the resulting iron uptake rate is similar in both groups.
\end{abstract}

Iron, despite its importance as an essential metal for all organisms and its abundance and ubiquity in nature, has very limited availability for microorganisms because of both its tendency to form highly insoluble complexes and its being sequestered by specialized molecules such as transferrin and lactoferrin. In order to increase their iron supply, many microorganisms, when grown under iron restriction conditions, synthesize siderophores, low molecular weight chelants with very high affinity for iron, that are able to extract this metal from sequestering macromolecules. Iron-siderophore complexes are trapped by specialized microbial outermembrane macromolecules and usually are taken up in an energy-coupled process across the outer and cytoplasmic membranes.

\footnotetext{
* Address reprint requests to: Dr. Carlos M. Ferreirós, Departamento de Microbiología y Parasitología, Facultad de Farmacia, Universidad de Santiago de Compostela, Spain.

Abbreviations: NDM, Neisseria defined medium; EDDA, ethylene-diamine-di-hydroxy-phenylacetic acid; MH, Mueller-Hinton broth; $K_{\mathrm{a}}$, affinity constant.
} 
Neisseria meningitidis grows readily in a wide range of environments as a result of being able to extract iron from various sequestering agents (5). West and Sparling (21) demonstrated that this ability is not mediated by the production of siderophores, but by a receptor system located in the outer mernbrane which only acts under iron restriction. Iron uptake from transferrin, for exarnple, needs direct contact between rransferrin and the bacterial wall (18) and involves iron-regulated outer membrane proteins that function as specific receprors $(1,6,10)$ and shows a highly variable inass (7). The binding process is stable and highly specific (17) and the transferrin is not internalized (14). So far, however, the biochernical mechanisms responsible for the extraction of iron from transfer rin and its transport through the outer and inner bacterial mernbranes have not been elucidated in depth.

Serurn and other biological fluids such as cerebrospinal fluid contain other iron sources besides transfer rin and lactoferrin; citric acid and lactic acid are efficient iron chelators, and bacteria able to obtain iron from them have obvious advantages over those forced to secrete their own siderophores. Moreover, iron bound to these organic acids, particularly citric acid, is taken up much more easily than that carried by transferrin, and constitutes an important source of this metal for pathogens such as $N$. meningitidis. The meningococcal system for uptake of iron from citrate is based on the presence of specific outer membrane receptors which bind iron borne in $\mathrm{Fe}^{3+}$-dicitrate complexes which have not been yet characterized $(3,19)$. However, citrate is not used as a source of carbon or energy, as in Escherichia coli $(19,20)$, but only as a shuttle for iron, the dissociation of netal and ligand taking place at the bacterial envelope and being followed by the internalization of iron alone $(12,19)$.

In $N$. meningitidis iron uptake from $\mathrm{Fe}^{3+}$-dicitrate is not inducible by the presence of the cornplex as it is in E. coli (9). Probably, an initial energyindependent phase in which interse non-specific, concentration-dependent binding takes place is followed by an energy-dependent phase in which iron uptake occurs via a high-affinity binding mechanism like uptake from ferric chloride (3) or transferrin (18).

In this paper we report the characteristics of energy-independent $\mathrm{Fe}^{3+}$-dicitrate iron binding system in various $N$. meningitidis strains, as well as the measurement of energy-dependent iron uptake in these microorganisms.

\section{MATERIALS AND METHODS}

Bacteria and growth conditions. Neisseria meningitidis strains P000, P391 and P636 were obtained from the oropharynx of healthy carriers. Strains V002, V019 and V021 were isolated from the cerebrospinal fluid of patients in our region. All strains are serogroup B, but differ in serotype. Serogrouping and serotyping were perforıned in the Centro Nacional de Microbiología, Virología e Inmunología at Majadahonda (Spain). An Escherichia coli K12 strain was used as a reference for positive control of ferric citrate receptors induction. All strains were stored at 
$-80^{\circ} \mathrm{C}$ in $5 \%$ sodium glutamate $-5 \%$ bovine albumin (16). For experiments, the strains were cultured as described previously ( 8 ). Briefly, one isolated colony from Choc-Iso agar plates incubated for $24 \mathrm{~h}$ at $37^{\circ} \mathrm{C}$ in a $5 \% \mathrm{CO}_{2}$ atmosphere, was cultured for $8 \mathrm{~h}$ under the same conditions as above before inoculation in $100 \mathrm{ml}$ of MH (in iron sufficiency). Iron restriction medium was MH containing the iron chelant EDDA at a final concentration of $39 \mu \mathrm{M}$ (MH-EDDA); medium for receptor induction experiments $\left(\mathrm{MH}-\mathrm{Fe}\right.$ ) was $\mathrm{MH}$ containing $1 \mu \mathrm{M} \mathrm{Fe}{ }^{3+}$-dicitrate ( $1 \mathrm{mM}$ sodium citrate: $1 \mu \mathrm{M} \mathrm{FeCl}_{3}$ ). All final cultures were incubated for $14 \mathrm{~h}$ at $37^{\circ} \mathrm{C}$ with constant shaking at $100 \mathrm{rpm}$. For Fe uptake measurements, the bacteria were cultured in NDM modified as described in Table 1 and deferrated by treatment with Chelex-100 (5); all material used was washed with $6 \mathrm{~N} \mathrm{HCl}$ and thoroughly rinsed with distilled deionized water. Briefly, $2 \mathrm{ml}$ of a preinoculum cultured in MH-EDDA were inoculated into Erlenmeyer flasks containing $100 \mathrm{ml}$ of NDM or NDM with $20 \mu \mathrm{M}$ ferric citrate (controls) and incubated for 8-10 h at $37^{\circ} \mathrm{C}$ and $100 \mathrm{rpm}$ constant shaking in a water bath.

Chemicals. $\left[{ }^{55} \mathrm{Fe}\right]$ Ferric chloride $(1-50 \mathrm{mCi} / \mathrm{mg} \mathrm{Fe})$ and $\left[{ }^{14} \mathrm{C}\right]$ citric acid (100-120 $\mathrm{mCi} / \mathrm{mmol}$ ) were obtained from Amersham International plc (Buckinghamshire, England). Isocitric, lactic, pyruvic and citric acids and EDDA were purchased from Merck, Darmstadt, Germany. MOPS was from Sigma Chemical Co. (St. Louis, MO, U.S.A.), and the scintillation cocktail (Ready-Protein) was obtained from Beckman Instruments Inc. (Fullerton, CA, U.S.A.). Complexes of iron with the organic acids were always prepared by mixing solutions of $\mathrm{FeCl}_{3}$ and organic acid at a 1/100 molar ratio, except in the case of EDDA in which molar ratio was $1 / 2$.

Table 1. Composition of the Neisseria defined medium (NDM).

\begin{tabular}{llc}
\hline \multicolumn{1}{c}{ Components } & Chemicals & Concentration (mM) \\
\hline Stock solution A $(25 \mathrm{ml} / l)$ & $\mathrm{NaCl}$ & 100.00 \\
& $\mathrm{~K}_{2} \mathrm{SO}_{4}$ & 5.70 \\
& $\mathrm{NH}_{4} \mathrm{Cl}$ & 4.11 \\
& $\mathrm{Na}_{2} \mathrm{EDTA}$ & 0.01 \\
& $\mathrm{MgCl}_{2}$ & 1.07 \\
& $\mathrm{~K}_{2} \mathrm{HPO}_{4}$ & 2.00 \\
Stock solution B $(20 \mathrm{ml} / l)$ & $\mathrm{KH}_{2} \mathrm{PO}_{4}$ & 2.00 \\
& $\mathrm{HEPES}$ & 21.00 \\
& $\mathrm{CaCl}_{2}$ & 0.25 \\
Stock solution C $(1 \mathrm{ml} / l)$ & $\mathrm{L}-\mathrm{Arginine}$ & 0.50 \\
Stock solution D $(250 \mathrm{ml} / l)$ & L-Cysteine & 0.06 \\
& L-Glycine & 2.00 \\
& L-Serine & 0.20 \\
& L-Glutamine & 8.00 \\
Stock solution E $(25 \mathrm{ml} / l)$ & Sodium lactate & 60.00 \\
Stock solution F $(25 \mathrm{ml} / l)$ & Glucose & 28.00 \\
\hline
\end{tabular}

All stock solutions, except sol. C, are added together at the indicated quantities and adjusted to $1 l$ with distilled, deionized water ( $\mathrm{pH}$ must be adjusted to $7.45 \pm 0.1$ ). The medium is then sterilized by filtration and sterile sol. $\mathrm{C}$ added after cooling. 
$\left[{ }^{55} \mathrm{Fe}\right] \mathrm{Fe}^{3+}$-dicitrate binding assays. Binding of $\left[{ }^{55} \mathrm{Fe}^{3} \mathrm{Fe}^{3+}\right.$-dicitrate to killed meningococci was determined by a modification of the methods described by Simonson et al. (19) and Harding and Royt (11). Briefly, bacteria grown in MH or MH-EDDA were obtained by centrifugation at $10,000 \times g$ for $10 \mathrm{~min}$, washed in $50 \mathrm{~mm}$ MOPS (pH 7.5) and adjusted to $10^{10} \mathrm{cfu} / \mathrm{ml}$ in the same buffer. $\mathrm{KCN}$ was then added to $60 \mathrm{~mm}$ and the bacteria incubated for $20 \mathrm{~min}$ at room temperature (the concentration of $\mathrm{KCN}$ needed to kill all the bacteria in the suspension was determined as $60 \mathrm{mM}$ by incubation for $20 \mathrm{~min}$ in serial dilutions of $\mathrm{KCN}$ followed by inoculation onto $\mathrm{MH}$ agar plates to determine viability). A $0.1 \mathrm{ml}$ sample of the suspension ( $10^{9}$ bacteria) was then mixed in $1.5 \mathrm{ml}$ Eppendorf tubes with $0.1 \mathrm{ml}$ of $\left[{ }^{55} \mathrm{Fe}\right] \mathrm{Fe}^{3+}$-dicitrate complex (specific activity $180 \mathrm{ct} / \mathrm{min} / \mathrm{pmol}$ ) and incubated at $20^{\circ} \mathrm{C}$. After incubation, bacteria were harvested by centrifugation at $15,000 \times g$ for $2 \mathrm{~min}$ and washed three times in $0.2 \mathrm{ml}$ of MOPS containing $2 \mu \mathrm{M} \mathrm{KCN}$ and $2.5 \mathrm{mM}$ sodium citrate. The bacterial pellet was finally suspended in $0.1 \mathrm{ml}$ of distilled water and the associated radioactivity measured in a scintillation counter. Non-specific binding was determined in parallel experiments in which $\mathrm{Fe}^{3+}$-dicitrate was added at a concentration 100 times higher than that of $\left[{ }^{55} \mathrm{Fe}\right] \mathrm{Fe}^{3+}$-dicitrate. All experiments were repeated three times.

Radioactivity counts were analyzed using a commercial radioligand binding analysis program (EBDA; Elsevier-Biosoft, Cambridge, U.K.) based on non-linear curve fitting techniques (15). Differences between groups were analyzed by the Mann-Whitney U test.

For calculation of saturation times, concentration of the $\left[{ }^{55} \mathrm{Fe}\right] \mathrm{Fe}^{3+}$-dicitrate complex was $2.5 \mu \mathrm{M}$ (referred to $\mathrm{Fe} ; 0.5 \mu \mathrm{Ci} / \mu \mathrm{g}$ ) and several incubation times, from 0 to $60 \mathrm{~min}$, were assayed. For calculation of the number of $\mathrm{Fe}^{3+}$-dicitrate receptors and their affinity constants $\left(K_{\mathrm{a}}\right)$, several concentrations of the $\left[{ }^{55} \mathrm{Fe}\right]$ $\mathrm{Fe}^{3+}$-dicitrate complex $(0.5,1,2,3,5,10,20$ and $30 \mu \mathrm{M} \mathrm{Fe}$; specific activity 180 $\mathrm{ct} / \mathrm{min} / \mathrm{pmol}$ ) and a $20 \mathrm{~min}$ incubation time were used.

Binding of ${ }^{55} \mathrm{Fe}$ chelated by other organic acids. The binding of ${ }^{55} \mathrm{Fe}$ chelated by isocitrate, lactate, pyruvate and EDDA was studied as described for citrate.

$\left[{ }^{14} \mathrm{C}\right]$ Citrate binding assays. Citrate binding was determined using $\mathrm{Fe}^{3+}$. $\left[{ }^{14} \mathrm{C}\right]$ dicitrate as described for $\left[{ }^{55} \mathrm{Fe}\right] \mathrm{Fe}^{3+}$-dicitrate, with the same $\mathrm{Fe}$ : citrate molar ratio and a specific activity of $247 \mathrm{ct} / \mathrm{min} / \mathrm{pmol}$. In this case, concentrations of $\mathrm{Fe}^{3+}$-dicitrate complex are referred to citrate.

${ }^{55} \mathrm{Fe}$ uptake measurement. Uptake of ${ }^{55} \mathrm{Fe}$ was measured by a modification of the method described by Harding and Royt (11). Briefly, bacteria cultivated in NDM as described above were suspended in deferrated MOPS (by Chelex-100 treatment) to $10^{6} \mathrm{CFU} / \mathrm{ml}$. Control bacteria were killed by incubation with $60 \mathrm{~mm}$ $\mathrm{KCN}$ for $20 \mathrm{~min}$. One hundred microliters of the suspensions were then incubated with $100 \mu 1$ of $60 \mu \mathrm{M}\left[{ }^{55} \mathrm{Fe}\right] \mathrm{Fe}^{3+}$-dicitrate in Eppendorf vials, and washed twice with deferrated MOPS after 1, 15, 30, 60, 120 and $180 \mathrm{~min}$. Counts associated to the bacteria were determined by liquid scintillation and converted to uptake rates as $\mathrm{pmol} / \mathrm{min} / 10^{9}$ cells. Uptake efficiencies of the receptors, here defined as uptake rate 
per receptor, were calculated dividing the total uptake by the time and the number of receptors in the $10^{9}$ cells in the assay.

\section{RESULTS}

$\left[{ }^{55} \mathrm{Fe}\right] \mathrm{Fe}^{3+}$-dicitrate binding assays

Figure 1 shows the time dependence of $\left[{ }^{55} \mathrm{Fe}\right] \mathrm{Fe}^{3+}$-dicitrate binding by $N$. meningitidis strain P000 (used as standard) in normal and in iron-restricted media. Binding increased with time, reaching saturation after about $10 \mathrm{~min}$. The same was observed for other strains (data not shown), and $20 \mathrm{~min}$ was considered time enough for saturation of the $\mathrm{Fe}^{3+}$-dicitrate receptor system.

The presence of $\mathrm{Fe}^{3+}$-dicitrate in the growth medium increased $\mathrm{Fe}^{3+}$-dicitrate binding by $E$. coli $\mathrm{K} 12$ about 20 fold (Fig. 2), implying an increase from a low number of receptors per cell (about 400$)$ to about $14,300\left(K_{\mathrm{a}}=1.7 \times 10^{6} \mathrm{l} / \mathrm{mol}\right)$. There was no statistically significant effect on binding by $N$. meningitidis $\left(K_{\mathrm{a}}=\right.$ $6.3 \times 10^{4}$ to $2.6 \times 10^{5}$; Table 2 ).

Figure 3 compares $\left[{ }^{14} \mathrm{C}\right]$ citrate binding by $N$. meningitidis $\mathrm{P} 000$ cells in the presence and absence of $\mathrm{Fe}^{3+}$. About 14,400 receptors per cell $\left(K_{\mathrm{a}}=1.6 \times 10^{4}\right.$ $l / \mathrm{mol})$ were calculated for sodium citrate and 21,000 receptors per cell $\left(K_{\mathrm{a}}=1 \times 10^{4}\right.$ $l / \mathrm{mol})$ for $\mathrm{Fe}^{3+}$-dicitrate complex. Although this difference is not statistically significant, it seems that the efficiency of citrate binding may be enhanced in the case of $\mathrm{Fe}^{3+}$ complexes.

Figures 4 and 5 show saturation and Scatchard plots for six $N$. meningitidis strains cultured both under normal and iron-restricted conditions. The strains differed mutually both in the number of receptors per cell and in the affinity

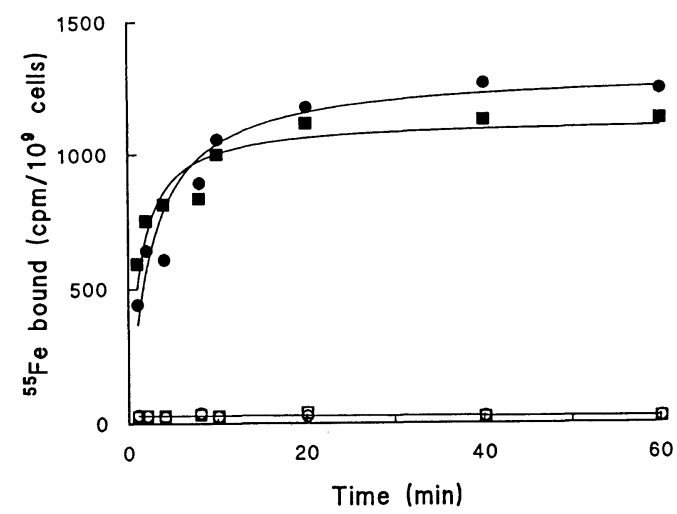

Fig. 1. Saturation time of $\left[{ }^{55} \mathrm{Fe}\right] \mathrm{Fe}^{3+}$-dicitrate complex binding in Neisseria meningitidis $\mathrm{P} 000$.

Squares indicate bacteria cultivated in Mueller-Hinton broth $(\mathrm{MH})$, and circles indicate bacteria cultivated in iron-restricted medium (MH with $39 \mu \mathrm{M}$ EDDA). Open symbols show the corresponding non-specific binding. 


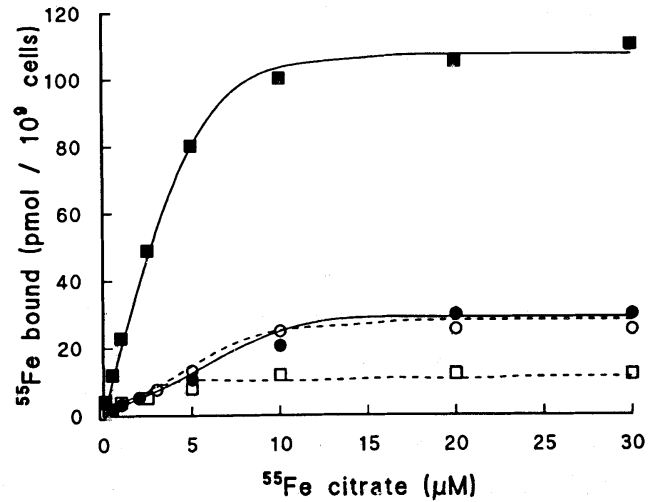

Fig. 2. Induction of $\left[{ }^{55} \mathrm{Fe}\right] \mathrm{Fe}^{3+}$-dicitrate receptors in Escherichia coli $\mathrm{K} 12$ (squares) and Neisseria meningitidis P000 (circles).

Open symbols correspond to cells grown without $\mathrm{Fe}^{3+}$-dicitrate. Solid symbols are from cells grown with ferric citrate ( $1 \mathrm{mM}$ sodium citrate : $1 \mu \mathrm{M}$ ferric chloride).

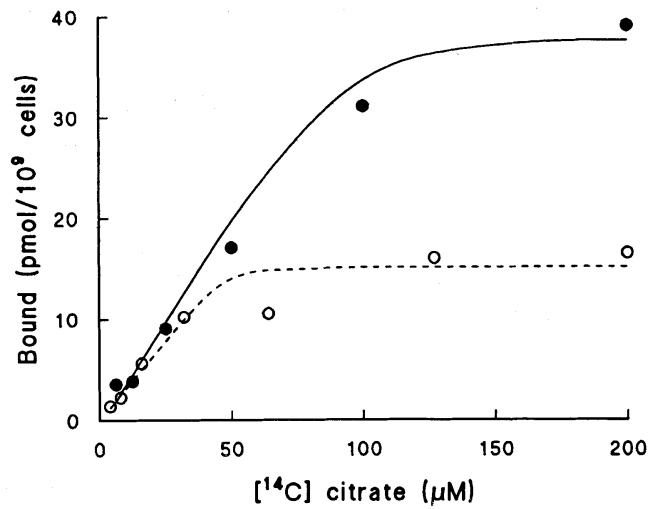

Fig. 3. Binding of $\mathrm{Fe}^{3+}-\left[{ }^{14} \mathrm{C}\right]$ dicitrate complex $(\bullet)$ and sodium $\left[{ }^{14} \mathrm{C}\right]$ citrate $(O)$ to Neisseria meningitidis $\mathrm{P} 000$ cells.

$\mathrm{Fe}^{3+}$-dicitrate was prepared at an ferric chloride : sodium citrate ratio of $1: 100$.

constant for $\mathrm{Fe}^{3+}$-dicitrate complex. The number of receptors depended on whether normal or iron-restricted culture conditions were used, especially for strain P391, but the affinity constants were practically unaffected by iron restriction. Table 2 lists, for the six strains, the values of the above parameters together with the maximum binding of $\mathrm{Fe}^{3+}$-dicitrate complex.

\section{Binding of ${ }^{55} \mathrm{Fe}$ chelated by other organic acids}

Figure 6 shows the results of binding experiments using different organic acids to carry iron. The binding kinetics were linear reflecting non-specific binding, and in keeping with this statistical analysis failed to afford the parameters corresponding 

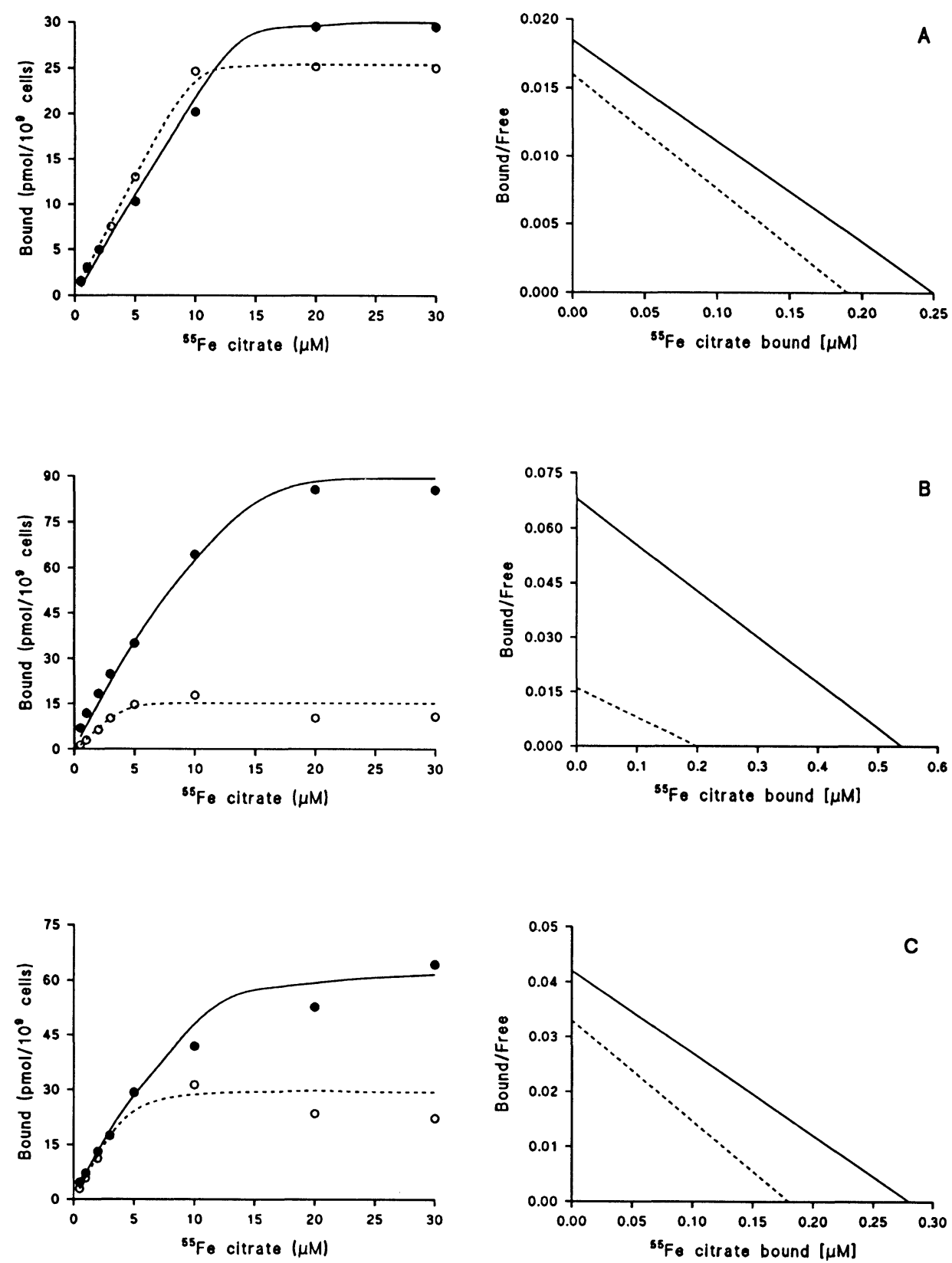

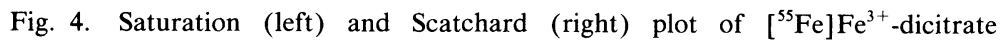
binding to three Neisseria meningitidis strains obtained from healthy carriers cultured under normal and iron-restricted culture.

A, strain P000; B, strain P391; C, strain P636. Open symbols corresponds to cells grown in iron sufficience (MH broth) and solid symbols are from cells grown in iron restriction (MH with $39 \mu \mathrm{M}$ EDDA). 

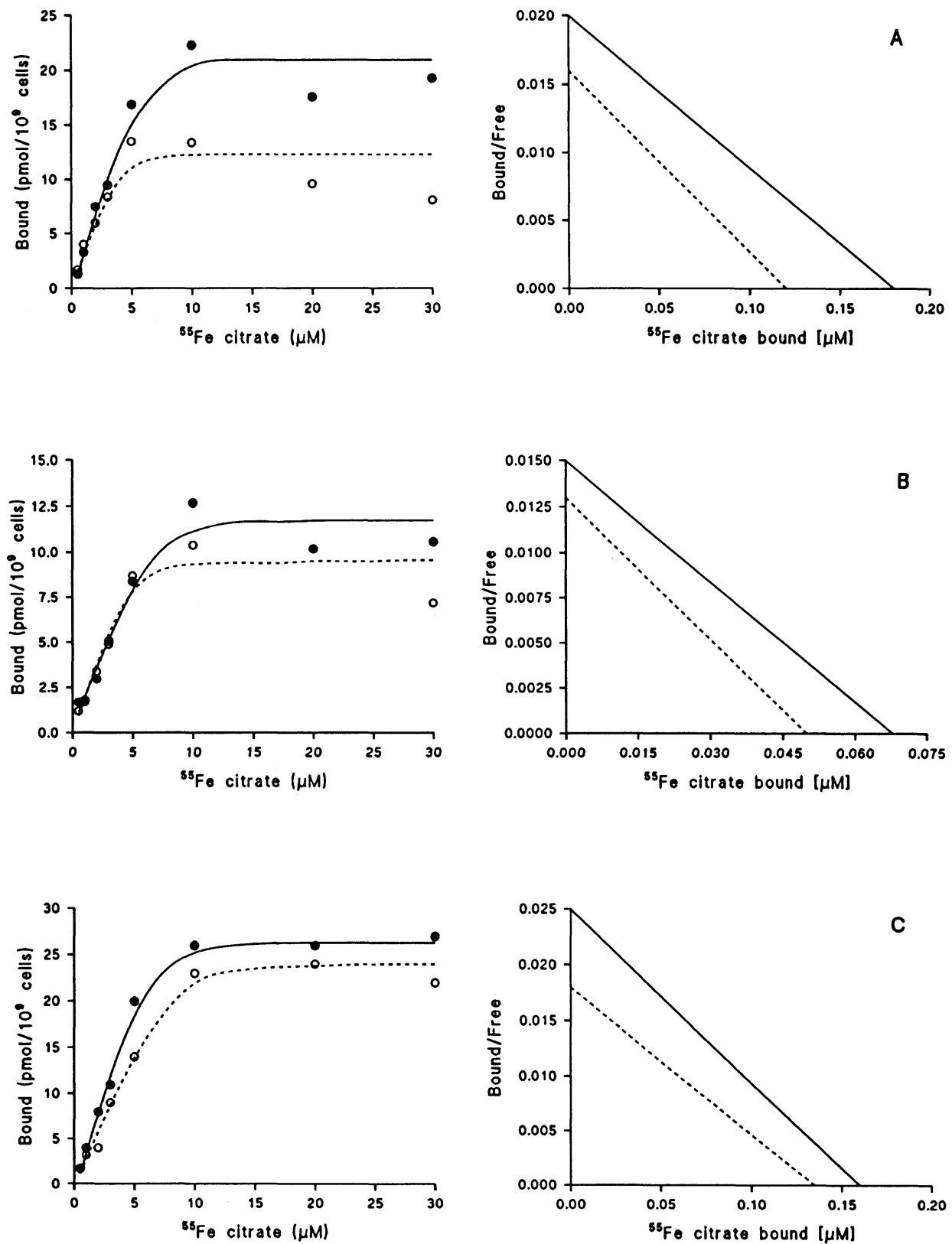

Fig. 5. Saturation (left) and Scatchard (right) plot of $\left[{ }^{55} \mathrm{Fe}\right] \mathrm{Fe}^{3+}$-dicitrate binding to three Neisseria meningitidis invasive strains cultured under normal and iron-restricted culture.

A, strain V002; B, strain V019; C, strain V021. Open symbols correspond to cells grown in iron sufficience (MH broth) and solid symbols are from cells grown in iron restriction (MH with $39 \mu \mathrm{M}$ EDDA). 
Table 2. Characteristics of the ferric dicitrate receptor systems present in six Neisseria meningitidis strains.

\begin{tabular}{|c|c|c|c|c|c|c|c|c|}
\hline \multirow[b]{2}{*}{ Strain } & \multicolumn{3}{|c|}{ Normal culture conditions } & \multicolumn{5}{|c|}{ Iron restriction } \\
\hline & $\begin{array}{c}\text { Binding } \\
\left(\mathrm{pmol} / 10^{9}\right)\end{array}$ & $\begin{array}{c}K_{\mathrm{a}} \\
(l / \mathrm{mol})\end{array}$ & $\begin{array}{c}\text { Receptors/ } \\
\text { Cell }\end{array}$ & $\begin{array}{c}\text { Binding } \\
\left(\mathrm{pmol} / 10^{9}\right)\end{array}$ & $\begin{array}{c}K_{\mathrm{a}} \\
(l / \mathrm{mol})\end{array}$ & $\begin{array}{c}\text { Receptors/ } \\
\text { Cell }\end{array}$ & $\begin{array}{l}\text { Fe uptake } \\
\text { rate }(\mathrm{pmol} / \\
\left.\min / 10^{9}\right)\end{array}$ & $\begin{array}{c}\text { Fe uptake } \\
\text { efficience (pmol/ } \\
\text { min/receptor) }\end{array}$ \\
\hline P000 & 24.6 & $9.3 \cdot 10^{4}$ & 22,500 & 29.5 & $6.3 \cdot 10^{4}$ & 29,400 & 0.91 & $31 \cdot 10^{-15}$ \\
\hline P391 & 17.8 & $6.3 \cdot 10^{4}$ & 24,600 & 85.5 & $2.0 \cdot 10^{5}$ & 64,800 & 1.35 & $20 \cdot 10^{-15}$ \\
\hline P636 & 31.2 & $2.4 \cdot 10^{5}$ & 21,700 & 64.3 & $1.5 \cdot 10^{5}$ & 33,700 & 1.63 & $48 \cdot 10^{-15}$ \\
\hline V002 & 13.5 & $2.6 \cdot 10^{5}$ & 14,500 & 20.0 & $1.1 \cdot 10^{5}$ & 21,400 & 1.46 & $68 \cdot 10^{-15}$ \\
\hline V019 & 8.6 & $2.6 \cdot 10^{5}$ & 6,200 & 11.7 & $2.1 \cdot 10^{5}$ & 8,500 & 0.47 & $55 \cdot 10^{-15}$ \\
\hline V021 & 13.9 & $1.4 \cdot 10^{5}$ & 15,300 & 26.1 & $1.5 \cdot 10^{5}$ & 19,700 & 1.00 & $51 \cdot 10^{-15}$ \\
\hline
\end{tabular}

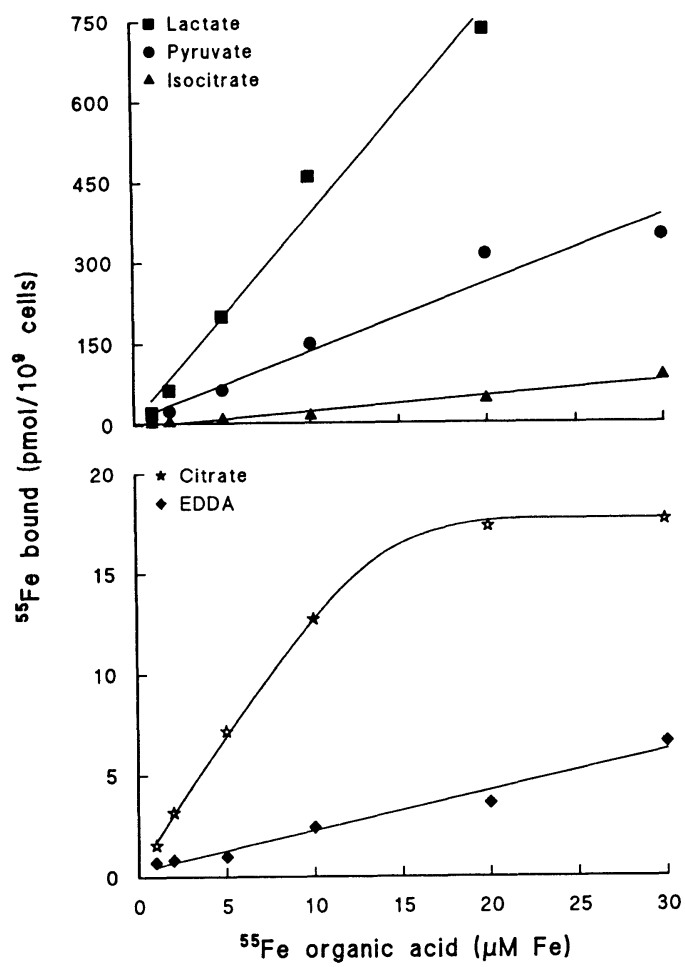

Fig. 6. Binding of iron chelated to various low molecular weight organic acids by Neisseria meningitidis cells grown in iron-restricted conditions.

to the assumption of a saturation kinetics (in contrast to the case of citrate). The extent of iron binding depended on the carrier; it was greatest for lactate and very low for EDDA. These results suggest that there are no specific receptors for iron bound to these organic acids as there are for citrate. 
Measurement of ${ }^{55} \mathrm{Fe}$ uptake

Table 2 shows the iron uptake rate and uptake efficiency from iron-citrate complexes in the six $N$. meningitidis strains used in this study, cultured under iron restriction (in NDM). As can be seen, there were found no differences in the uptake rates in carrier and invasive strains ( $p=0.5$; Mann Whitney $U$ test), whereas uptake efficiency was significatively higher $(p<0.05$; Mann Whitney $U$ test $)$ in the last group.

\section{DISCUSSION}

Many microorganisms, including $N$. meningitidis (3), E. coli (20) and Pseudomonas aeruginosa (4) are capable of taking up iron directly from naturally occurring iron-binding acidic siderophores such as citrate, $N$. meningitidis being able to use also malate, pyruvate and isocitrate for that purpose (2). This phenomenon has been most intensively studied in the case of $E$. coli; studies with $N$. meningitidis have hitherto mainly focused on quantifying iron uptake rather than on characterizing the uptake system. It is known, however, that in both $E$. coli and $N$. meningitidis the uptake system involves the production of outer membrane receptors that recognize extracellular iron-citrate complexes $(9,19,20)$. Iron and citrate are dissociated at the cell envelope (12) by an energy-independent mechanism (19).

In $E$. coli, citrate-dependent $\mathrm{Fe}^{3+}$ binding is enhanced by prior growth in the presence of citrate. That this does not occur in the case of $N$. meningitidis has been shown by Simonson et al. (19) and is confirmed by the results of this work (Fig. 2). We did, however, find that citrate-dependent iron binding was increased by culture in iron-restricted conditions, especially in the case of strain P391 (Table 2).

Archibald et al. (3) and Simonson et al. (19) reported that citrate was not bound by KCN-treated $N$. meningitidis either in the presence or in the absence of iron. Citrate was thus regarded as acting as a shuttle transporting iron to the cell from the extracellular medium (in particular, it did not itself act as a source of carbon or energy). In our experiments, on the other hand, we found that $\left[{ }^{14} \mathrm{C}\right]-$ citrate was bound both as $\mathrm{Fe}^{3+}$-dicitrate complex and as sodium citrate, though binding was less in the latter case (Fig. 3). The possibility that binding of citrate could be non-specific would appear to be ruled out by the fact that, although the binding of iron borne by isocitrate, lactate, pyruvate and EDDA was estimated as lineal by the analysis software used, which clearly indicates its non-specificity, whereas the binding of dicitrate-borne iron exhibited saturable kinetics. The linear kinetics of the non-citrate carriers likewise appear to rule out the possibility that the difference between citrate binding in the presence and absence of iron may have been due to some of the $\mathrm{Fe}^{3+}$-dicitrate having bound to $\mathrm{Fe}$ receptors not requiring the presence of citrate, whose existence has been suggested by Archibald et al. (3). We therefore propose that in $N$. meningitidis there is an iron uptake system that involves receptors that are specific for citrate, especially for citrate complexed to 
iron; these receptors are not induced by the presence of $\mathrm{Fe}^{3+}$-dicitrate.

It has been suggested that the metabolically efficient uptake of iron from iron-citrate complexes may be of importance for microbial pathogenicity (19) and for the in vivo survival of micro-organisms in disseminated disease (13). In our experiments, invasive and carrier strains of $N$. meningitidis did not differ significantly as regards total binding, the affinity constant for citrate-dependent iron binding, and the iron uptake rate, being the differences in receptor numbers compensated by those in uptake efficiency. We accordingly believe that uptake of iron from $\mathrm{Fe}^{3+}$-dicitrate cannot be considered a marker of virulence in $N$. meningitidis, and that this source of iron is not as important for $N$. meningitidis as it is for bacteria such as $E$. coli or $P$. aeruginosa. Uptake experiments are being continued to draw conclusions about the possible role of iron-dicitrate uptake in pathogenicity.

We wish to acknowledge Prof. Dr. J. Espinosa (Dept. of Physiology, University of Santiago de Compostela, Spain) for his helpful theoretical assistance with the calculations and interpretation of receptor experiments.

\section{REFERENCES}

1) Ala'Aldeen, D. A., Davies, H. A., and Wall, R. A., The 70 kilodalton iron-regulated protein of Neisseria meningitidis is not the human transferrin receptor. FEMS Microbiol. Lett., 69, 69376942 (1990).

2) Archibald, F. S. and DeVoe, I., Iron acquisition by Neisseria meningitidis in vitro. Infect. Immun., 27, 322-334 (1990).

3) Archibald, F. S., Simonson, C., and DeVoe, I., Comparison of iron binding and uptake from $\mathrm{FeCl}_{3}$ and Fe-citrate by Neisseria meningitidis. Can. J. Microbiol., 27, 1066-1070 (1981).

4) Cox, C. H. D., Iron uptake with ferripyochelin and ferric citrate by Pseudomonas aeruginosa. J. Bacteriol., 142, 581-587 (1980).

5) Dyer, D. W., West, E. P., Mckenna, W., Thompson, S. A., and Sparling, P. F., A pleiotropic iron uptake mutant of Neisseria meningitidis lacks a $70 \mathrm{kDa}$ iron regulated protein. Infect. Immun., 56, 977-983 (1988).

6) Ferreirós, C. M., Criado, M. T., Del Rio, M. C., and Pintor, M., Analysis of the expression of outer-membrane proteins in Neisseria meningitidis in iron-replete and iron-deficient media. FEMS Microbiol. Lett., 71, 49-54 (1990).

7) Ferreirós, C. M., Criado, M. T., Pintor, M., and Ferrón, L., Analysis of the molecular mass heterogeneity of the transferrin receptor in Neisseria meningitidis and commensal Neisseria. FEMS Microbiol. Lett., 83, 247-254 (1991).

8) Ferrón, L., Ferreirós, C. M., Criado, M. T., and Pintor, M., Immunogeneity and antigenic heterogeneity of a human transferrin-binding protein in Neisseria meningitidis. Infect. Immun., 60, 2887-2892 (1992).

9) Frost, G. E. and Rosemberg, H., The inducible citrate dependent iron transport system in Escherichia coli K12. Biochim. Biophys. Acta, 330, 90-101 (1973).

10) Griffiths, E., Stevenson, R., and Ray, A., Antigenic and molecular heterogeneity of the transferrin binding protein of Neisseria meningitidis. FEMS Microbiol. Lett., 69, 31-36 (1980).

11) Harding, R. A. and Royt, P. W., Acquisition of iron from citrate by Pseudomonas aeruginosa. J. Gen. Microbiol., 136, 1859-1867 (1990).

12) Hussein, S., Hantke, M., and Braun, V., Citrate-dependent iron transport system in Escherichia coli K12. Eur. J. Biochem., 117, 431-437 (1981). 
13) Kochan, I., The role of iron in bacterial infections with special consideration of host-tubercle bacillus interaction. Curr. Top. Microbiol. Immunol., 60, 1-30 (1973).

14) Mckenna, W. R., Mickelsen, P. A., Sparling, P. F., and Dyer, D. W., Iron uptake from lactoferrin and transferrin by Neisseria gonorrhoeae. Infect. Immun., 56, 785-791 (1988).

15) Mcpherson, G. A., Analysis of radioligand binding experiments: A collection of computer program for IBM PC. J. Pharmacol. Methods, 14, 213-228 (1985).

16) Salit, I. E., Haemagglutination by Neisseria meningitidis. Can. J. Microbiol., 27, 586-593 (1981).

17) Schryvers, A. B. and Morris, I. J., Identification and characterization of the transferrin receptor from Neisseria meningitidis. Mol. Microbiol., 2, 281-288 (1988).

18) Simonson, C., Brener, D., and DeVoe, I. W., Expression of a high-affinity mechanisms for acquisition of transferrin iron by Neisseria meningitidis. Infect. Immun., 36, 107-113 (1982).

19) Simonson, C., Trivett, T., and DeVoe, I. W., Energy-independent uptake of iron from citrate by isolated outer membranes of Neisseria meningitidis. Infect. Immun., 31, 547-553 (1981).

20) Wagegg, W. and Braun, V., Ferric citrate transport in Escherichia coli requires outer membranes receptor protein FecA. J. Bacteriol., 145, 156-163 (1981).

21 ) West, S. E. H. and Sparling, P. F., Response of Neisseria gonorrhoeae to iron limitation: Alteration in expression of membrane proteins without apparent siderophore production. Infect. Immun., 47, 388-394 (1985). 